\title{
Social objectives of fisheries management: What are managers' priorities?
}

\author{
Sean Pascoe a, *, Kate Brooks ${ }^{b}$, Toni Cannard ${ }^{a}$, Catherine M. Dichmont ${ }^{a}$, Eddie Jebreen ${ }^{\text {, }}$ \\ Jacki Schirmer ${ }^{\text {, }}$, Lianos Triantafillos ${ }^{\text {e }}$ \\ a CSIRO Marine and Atmospheric Research, P.O. Box 2583, Brisbane, QLD 4001, Australia \\ ${ }^{\mathrm{b}}$ Kalanalysis, P.O. Box 3287, Prahran East, VIC 3181, Australia \\ c Queensland Department of Agriculture, Fisheries and Forestry, GPO Box 46, Brisbane, QLD 4001, Australia \\ ${ }^{d}$ Faculty of Health, University of Canberra, University Drive South, ACT 2617, Australia \\ e Department of Primary Industries and Regions SA, GPO Box 1625, Adelaide, SA 5001, Australia
}

\section{A R T I C L E I N F O}

Article history:

Available online 19 June 2014

\begin{abstract}
A B S T R A C T
Increasingly, social considerations are having an influence on fisheries policy as well as day-to-day management decision making. Social objectives, unlike economic or conservation objectives, are often poorly defined in fisheries policy, providing substantial leeway for managers to develop management plans in response to the perceived importance of different social outcomes, and potential inconsistencies between different fisheries and jurisdictions. In this paper, through a literature review and workshop with managers across different Australian jurisdictions, we develop a set of social objectives that may be applicable in Australian fisheries. We assess the importance of these different objectives using the Analytic Hierarchy Process, and find considerable diversity in opinion as to which social objectives fisheries management should prioritise to achieve. This diversity of opinion is not directly related to jurisdiction, but does seem related to the context and social environment in which fisheries managers are operating.
\end{abstract}

Crown Copyright (c) 2014 Published by Elsevier Ltd. All rights reserved.

\section{Introduction}

Fisheries management policy in most countries is largely concerned with achieving a similar set of objectives, namely biological, economic, social, political and environmental objectives (Cochrane, 2000; Hilborn, 2007). However, social objectives are generally vague in both their definition and relative importance. Fisheries management has historically been dominated by biological objectives relating to the maximisation of sustainable production from the fishery, as most fisheries managers and policy makers have largely emerged from a biological background (Ward and Kelly, 2009). More recently, economic objectives have increased in importance, at least in some countries, with maximum economic yield being a key management objective (Dichmont et al., 2010), and economists are increasingly playing a direct role in fisheries management and policy formulation. Social objectives, however, have largely languished in the background (Hall and Mainprize, 2004; Symes and Hoefnagel, 2010; Symes and Phillipson, 2009).

\footnotetext{
* Corresponding author. Tel.: +61 738335966.

E-mail address: sean.pascoe@csiro.au (S. Pascoe).
}

Clear objective definition for fisheries management is fundamental to management success. Objectives provide a transparent guide to what the management aims to achieve, identify potential conflicting activities, guide elements of the decision making process, and ensure accountability of personnel within the management agency (Barber and Taylor, 1990). Several potential explanations have been proposed for the lack of succinct social objectives in fisheries management. One proposed explanation is the much smaller and more fragmented nature of the fisheries social science community, and the preference for many social scientists to act as an independent critical conscience denouncing the weaknesses and failures of fisheries management (Phillipson and Symes, 2013). Some claim that there is a lack of understanding of social ethos, context and relationships of the fishing industry and related communities (Symes and Phillipson, 2009), and/or a lack of a critical mass of social scientists with an interest in fisheries and fisheries policy (Symes and Hoefnagel, 2010). Others argue that, unlike economists and ecologists who share a common ontology based on quantitative methodologies and models, social scientists tend to employ more perceptive, inductive and qualitative approaches that are less structured, measurable and replicable (Urquhart et al., 2011). As a result, a consistent set of social 
objectives has not evolved in the same way as they have in the more quantitative management components.

The increasing adoption of ecological sustainable development (ESD) principles for fisheries management globally (Chesson et al., 1999; Garcia and Cochrane, 2005; Liu et al., 2005) has required consideration of the whole natural, economic and social environment in which fishing is undertaken. As a result, there is renewed interest in how social objectives may be developed and measured (Coulthard, 2012; Plagányi et al., 2013). ESD requires integrated management of social development, economic growth and environmental protection (Jabareen, 2008). To achieve this, national plans need to include goals and objectives for each of the components in order to guide national rules, regulations and law to achieve them (Jabareen, 2008).

Within Australia, as in many countries, sustainable development principles are increasingly being included in key fisheries legislation to varying degrees. While not all countries have formally adopted an ESD framework, other common frameworks, such as a livelihood approach framework (Allison and Ellis, 2001) similarly include the need to develop social objectives, while most countries at least reference the need to consider social outcomes of management (Mardle et al., 2002; OECD, 2012). Less well defined is how these principles are to be implemented in practice. There is also considerable diversity of opinion as to the relative importance of the different components (i.e. ecological, economic and social), and how these should be considered within the ESD and similar frameworks. Internationally, some argue that the single biggest cause of failure in fisheries management is that too much emphasis is given to economic and social objectives rather than ecological objectives (Cochrane, 2000). Others assert that too little attention is paid to social values, objectives and drivers (Daw and Gray, 2005; Symes and Phillipson, 2009). Previous studies of fisheries management objectives in Australia have found widely varying importance given to social, economic and environmental objectives both between Federal and State policy and also between different stakeholders (Pascoe et al., 2013a, 2009b).

In this paper, we begin to address the gap in current development and use of social objectives in fisheries management, through developing a series of objectives for the social components of ESD relevant to both Federal and State managed fisheries in Australia, and determining their relative importance using the analytic hierarchy process (AHP). We also examine the coherency of the objective weights across the different jurisdictions, and consider what factors may affect differences in opinion. While developed within the Australian context, it is expected that the key objectives identified would be applicable in many other countries with similar social values, and that the approach used in this study could act as a blueprint for developing and assessing appropriate social objectives elsewhere.

\section{Methods}

\subsection{Identification of social objectives relevant to the Australian context}

While many lament the lack of social objectives in formal management decision making (e.g. Symes and Hoefnagel, 2010; Symes and Phillipson, 2009; Urquhart et al., 2011), a wide range of social objectives have been used in fisheries analyses (Table 1). The most common objectives (in terms of number of studies in which they were considered) involved maintaining or enhancing family incomes and livelihoods, maintaining or maximising employment, maintaining communities and equity (Table 1 ). In most of the studies, these objectives were not formally included in management plans, but were considered key implicit objectives for the fisheries.

The set of social objectives for this study were developed in collaboration with fisheries and conservation managers across all Australian jurisdictions, as well as with input from industry and recreational peak bodies. A workshop was held in 2011 to establish: 1) a common understanding of the necessity of including a social component in fisheries management; and 2) to generate discussion around the range of possible objectives and identify which objectives are most appropriate. The workshop was attended by twenty industry managers and representatives, including fisheries managers from all jurisdictions (State and Commonwealth), as well as a number of other stakeholders (Fig. 1). The project team presented the range of objectives that had been identified through a review of the fisheries literature as a starting point for discussions. Participants were not limited to these objectives, and the workshop facilitator actively encouraged participants to extend their ideas and input beyond what they were seeded with.

Participants were also presented with a set of criteria which they were asked to use in order to assess the relevancy of potential objectives. The participants were asked firstly to consider to what extent they had the ability (as managers) to influence each objective either directly or indirectly. An objective that could not realistically be achieved through management actions was not considered a suitable candidate. The second criterion was consideration of whether it is possible to identify measurable indicators to monitor progress toward the achievement of the objective. If outcomes against an objective could not be measured, then again it was not considered a viable objective. This resulted in some desirable objectives being discarded, however in other cases it resulted in the objective being reviewed to focus specifically on those elements that fisheries agencies do have control or influence over and can measure progress towards.

Objectives relating to indigenous communities were developed separately in consultation with indigenous fisheries managers in Queensland, Northern Territory and South Australia, using the same criteria as in the broader workshop.

\subsection{Prioritising objectives}

Assessing the relative importance of different objectives is important when assessing overall performance of management as well as determining which objectives require greater attention in terms of information collection.

The method used to determine objective weightings in this study was the Analytic Hierarchy Process (AHP) (Saaty, 1980). AHP has been used in a number of fisheries applications to determine management objective importance and assist in decision making (Himes, 2007; Leung et al., 1998; Mardle et al., 2004; Nielsen and Mathiesen, 2006; Pascoe et al., 2009a,b, 2013a; Soma, 2003; Wattage and Mardle, 2005). It was an ideal method to use to identify which of the many social objectives initially identified were considered most important by Australian fisheries managers, and to compare priorities across fisheries jurisdictions.

AHP is based upon the construction of a series of pair-wise comparison matrices which compare objectives to one another, and a hierarchical structure that groups similar objectives into subgroups, and builds the hierarchy with progressive layers of groupings. The pair-wise comparison method makes the process of assigning weights much easier for participants because only two elements or objectives are being compared at any one time rather than all objectives having to be compared with each other simultaneously. Preferences are expressed on a nine point scale, with a 1 indicating equal preference, and a 9 indicating an extreme preference for one of the objectives. Preferences are assumed 
Table 1

Social objectives relating to fisheries management.

\begin{tabular}{|c|c|c|c|}
\hline Objective & Commercial fisheries & Recreational fisheries & Indigenous fisheries \\
\hline $\begin{array}{l}\text { Maintain or enhance family } \\
\text { incomes and livelihoods }\end{array}$ & $\begin{array}{l}\text { Chesson et al. (1999); Coulthard (2012); Davis and Wagner (2006); } \\
\text { Glaser and Diele (2004); Hilborn (2007); Lane (1989); Leung et al. (1998); } \\
\text { Marshall (2007); Mascia (2003); Soma (2003); Stouten et al. (2011); Symes } \\
\text { and Phillipson (2009); Tobin et al. (2009); Urquhart et al. (2011) }\end{array}$ & & $\begin{array}{l}\text { Andalecio (2011); } \\
\text { Plagányi et al. (2013) }\end{array}$ \\
\hline $\begin{array}{l}\text { Maintain or maximise } \\
\text { employment }\end{array}$ & $\begin{array}{l}\text { Chesson et al. (1999); Cheung and Sumaila (2008); Fulton et al. (2007); } \\
\text { Hilborn (2007); Mardle et al. (2002); Mardle et al. (2004); Nunan (2013); } \\
\text { Pascoe et al. (2013a); Stouten et al. (2011); Symes and Phillipson (2009); } \\
\text { Urquhart et al. (2011) }\end{array}$ & & Plagányi et al. (2013) \\
\hline Maintain communities & $\begin{array}{l}\text { Fulton et al. (2007); Hilborn (2007); Mardle et al. (2002); Mardle et al. } \\
\text { (2004); Marshall (2007); Pascoe et al. (2009b); Symes and Phillipson } \\
\text { (2009); Tobin et al. (2009); Urquhart et al. (2011) }\end{array}$ & $\begin{array}{l}\text { Cowx and Van } \\
\text { Anrooy (2010) }\end{array}$ & Plagányi et al. (2013) \\
\hline Equity & $\begin{array}{l}\text { Andalecio (2011); Davis and Wagner (2006); Fulton et al. (2007); Glaser } \\
\text { and Diele (2004); Mardle et al. (2004); Marshall (2007); Nunan (2013); } \\
\text { Pascoe et al. (2013a); Tobin et al. (2009) }\end{array}$ & & Plagányi et al. (2013) \\
\hline Maintain social capital & $\begin{array}{l}\text { Brooks (2010); Davis and Wagner (2006); Marshall (2007); Soma (2003); } \\
\text { Urquhart et al. (2011) }\end{array}$ & & \\
\hline Ensure health and safety & Coulthard (2012); Mardle et al. (2002); Nunan (2013); Soma (2003) & & \\
\hline $\begin{array}{l}\text { Conserve traditional activities, } \\
\text { culture and products }\end{array}$ & $\begin{array}{l}\text { Chesson et al. (1999); Davis and Wagner (2006); Leung et al. (1998); } \\
\text { Tobin et al. (2009); Urquhart et al. (2011) }\end{array}$ & $\begin{array}{l}\text { Cowx and } \\
\text { Van Anrooy (2010) }\end{array}$ & Plagányi et al. (2013) \\
\hline $\begin{array}{l}\text { Maintain or improve } \\
\text { recreational access }\end{array}$ & Leung et al. (1998); Mapstone et al. (2008) & $\begin{array}{l}\text { Leung et al. (1998); } \\
\text { Mapstone et al. (2008) }\end{array}$ & \\
\hline $\begin{array}{l}\text { Maintain or enhance } \\
\text { resilience }\end{array}$ & $\begin{array}{l}\text { Brooks (2010); Marshall (2007, 2010); Marshall and Marshall (2007); } \\
\text { Tobin et al. (2009); Urquhart et al. (2011) }\end{array}$ & & \\
\hline Enhance quality of life & $\begin{array}{l}\text { Coulthard (2012); Lane (1989); Leung et al. (1998); Schirmer and } \\
\text { Casey (2005); Tobin et al. (2009) }\end{array}$ & & \\
\hline $\begin{array}{l}\text { Avoid social exclusion } \\
\quad \text { (improve public perception) }\end{array}$ & Fulton et al. (2007); Symes and Phillipson (2009) & & \\
\hline $\begin{array}{l}\text { Minimise conflicts between } \\
\text { alternative users }\end{array}$ & $\begin{array}{l}\text { Andalecio (2011); Davis and Wagner (2006); Fulton et al. (2007); } \\
\text { Leung et al. (1998); Mardle et al. (2002); Mardle et al. (2004); } \\
\text { Pascoe et al. (2009b) }\end{array}$ & $\begin{array}{l}\text { Cowx and Van } \\
\text { Anrooy (2010) }\end{array}$ & \\
\hline Ensure food supply & Chesson et al. (1999) & & \\
\hline Ensure management stability & Fulton et al. (2007) & & \\
\hline Ensure management acceptability & Andalecio (2011) & & \\
\hline
\end{tabular}

symmetrical, such that if A against B has a preference of $a_{A B}=9$, then $a_{B A}=1 / a_{A B}=1 / 9$. For each set of comparisons, a matrix of scores can be developed, given by:

$A=\left[\begin{array}{cccc}a_{11} & a_{12} & \ldots & a_{1 n} \\ a_{21} & a_{22} & \ldots & a_{2 n} \\ \ldots & \ldots & \ldots & \ldots \\ a_{n 1} & a_{n 2} & \ldots & a_{n n}\end{array}\right]$

The scores are normalised by dividing through each element of the matrix by the sum of the column $j$ (i.e. summed over $i$, such that $\bar{a}_{i j}=a_{i j} / \sum a_{i j}$, and the weight associated with each objective can be estimated as the average of the normalised scores across the row $i$. That is, $w_{i}=\sum_{j} \bar{a}_{i j} / n$, where $n$ is the number of objectives being
compared.

The pair-wise comparisons and analyses are undertaken at the different levels of the hierarchy. That is, pair-wise comparison and analyses are made at different levels of aggregation, and the weight $w_{i}^{\ell}$ is estimated (the superscript $\ell$ indicating the level of the objective in the hierarchy). The analysis within each level of aggregation in the hierarchy is then undertaken, and the weights of the individual objectives are determined by the product of their initial weight estimate (i.e. when compared with the other objectives that they are grouped with) multiplied by the weight of the higher order aggregation (i.e. which is compared with other higher order aggregations). This reduces the number of direct comparisons

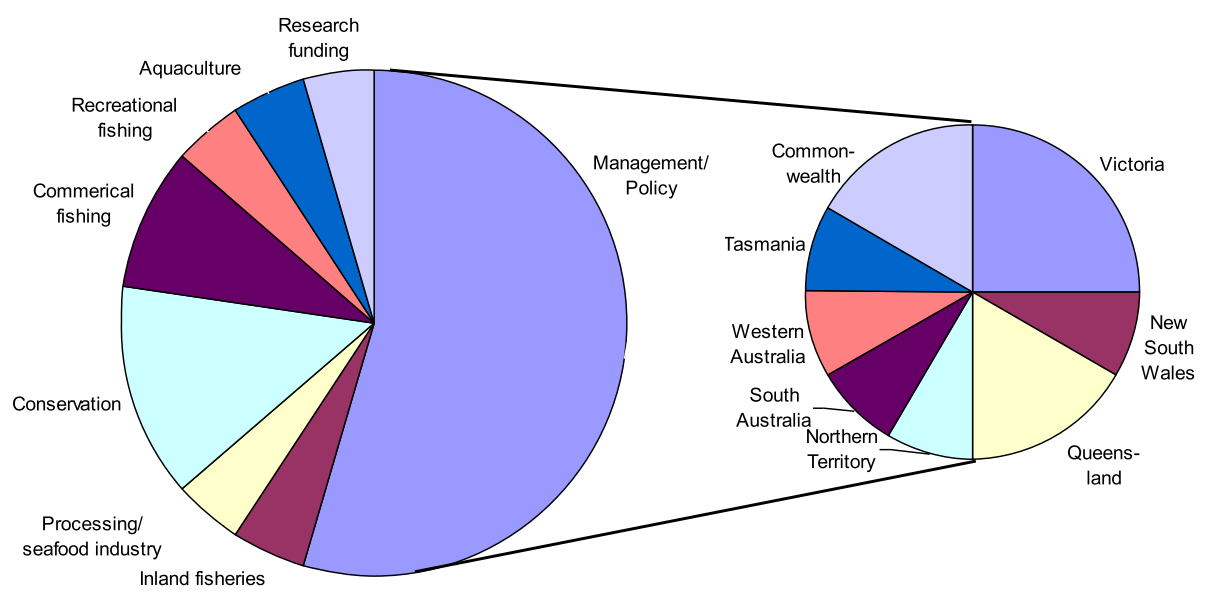

Fig. 1. Composition of the workshop participants. The smaller pie chart represents the jurisdictional distribution of the managers and policy makers. 
that need to be made, as only objectives at the same level and within the same broader objective need to be compared.

Preference weightings are highly subjective, and inconsistency is a common problem facing AHP, particularly when decision makers are confronted with many sets of comparisons (Bodin and Gass, 2003). Respondents do not necessarily cross check their responses, and even if they do, ensuring a perfectly consistent set of responses when many objectives are compared is difficult. The discrete nature of the 1-9 scale can also contribute to inconsistency, as a perfectly consistent response may require a fractional preference score.

The degree of consistency in the results can be assessed using the consistency index $(\mathrm{CI})$, given by

$C I=\frac{\lambda_{\max }-n}{n-1}$

where $\lambda_{\max }$ is the maximum eigenvalue of the matrix $A$ (see Equation (1)), given by $\lambda_{\max }=\sum_{i} \sum_{j} a_{i j} w_{i}$ (Duke and Aull-Hyde, 2002). This is compared to a randomly generated value for an $n \times n$ matrix (Random Indicator or RI) to derive a consistency ratio, $C R$, where $C R=C I / R I$. Values of $C R \leq 0.1$ are generally considered acceptable (Saaty, 1980), although higher measures are often accepted in fisheries analyses (Himes, 2007).

Objective weightings represent individual preferences, whereas policy development and fisheries management require a single set of weightings that reflect the views of the main stakeholders concerned. The level of group coherence indicates the degree to which members of a given stakeholder group have similar or dissimilar objective preferences. Zahir (1999a,b) developed a measure of group coherence for use in AHP studies, given by

$\bar{\rho}=\left\langle v_{i} \cdot v_{j}\right\rangle \quad i \neq j$

where $v_{i}$ and $v_{j}$ are vectors comprising the square root of the objective weights of individuals $i$ and $j$; • indicates the dot product of the two vectors, and \langle\rangle indicates the average of the set of dot products (Zahir, 1999a). The coherence measure, $\bar{\rho}$, represents the average angle between the individual vectors $\left(\cos \theta=\rho_{i, j}=v_{i} \bullet v_{j}\right.$ for a pair of individuals), such that $\cos 0^{\circ}=1$ implies identical preferences and $\cos 90^{\circ}=0$ implies orthogonal preferences. The closer the value is to 1 , the greater the average agreement in opinion of the individuals. While this has the appearance of a statistical measure, there is no generally accepted critical value. Some authors have adopted 99\%, 95\% and $90 \%$ as critical measures (Mardle et al., 2004), while others have developed other definitions of strong and weak coherence with wider intervals (Himes, 2007; Innes and Pascoe, 2010). Zahir (1999b) suggests the consideration of the proportion of "extreme cases" within a group, with extreme cases being those that have individual coherence measures $\rho_{i j}<(n+4) /(n+8)$, and $n$ being the number of objectives being examined. These effectively indicate substantial differences of opinion between individuals within a group. Hence, the proportion of comparisons between individuals that are considered extreme is another indicator of group coherence.

\subsection{AHP survey}

An MS Excel spreadsheet that enabled immediate feedback to participants on the implications of their preferences to particular objective weights and also their level of consistency was developed. The feedback build into the spreadsheet enabled managers to reassess their preferences if problems of inconsistency become apparent or if the resultant weightings were not as anticipated. An example of one sheet of the interactive survey instrument is given in Figure S1 in the supplementary material.
The survey was sent to all Australian State and Commonwealth agencies with a responsibility for fisheries management or policy. Within Australia, some fisheries are managed by States, and others by the Commonwealth government, meaning there are many different fisheries jurisdictions. Individuals attending the workshop were appointed as initial contact points, who then distributed the survey to others in their agency with management responsibilities. Other stakeholder groups (e.g. fishers, conservation groups and community groups) were not included in the survey as the aim was to assess managers' perceptions of the relative importance of the alternative objectives. Potentially, other stakeholders could be included in the analysis as has been done in other studies (Innes and Pascoe, 2010; Pascoe et al., 2013a). Who to include in the study was discussed at the stakeholder workshop, where the decision to limit it to managers - at least in the first instance - was made on the basis that they were responsible for implementing and achieving these objectives on behalf of the broader community.

In total, 78 individuals completed the AHP survey (Fig. 2). Individual responses were received from all states except New South Wales, which sent a single combined response representing ten individuals.

Several of the agencies requested that their results not be identified separately. The results were therefore grouped into southern states (New South Wales, Victoria, Tasmania, South Australia and Western Australia), northern states (Queensland, Northern Territory) and Commonwealth agencies (Department of Agriculture, Forestry and Fisheries, Australian Fisheries Management Authority and Great Barrier Reef Marine Park Authority). The southern states have fisheries mostly based on temperate species while the northern states are dominated by fisheries that harvest tropical species. While Western Australia has both temperate and tropical fisheries, the greatest value fisheries are temperate so it was included in the southern states.

\section{Results}

\subsection{Social objectives}

From the workshops and subsequent feedback based discussions with participants, 20 objectives were identified that can be grouped into outcomes affecting three separate communities (Table 2). The first community involved those actively engaged in fishing, either commercially, recreationally or as charter operations, and were collectively considered as "industry". The second community involved indigenous groups that had a traditional or cultural involvement with fishing. Commercial indigenous fishers were considered to form part of the first group. The third

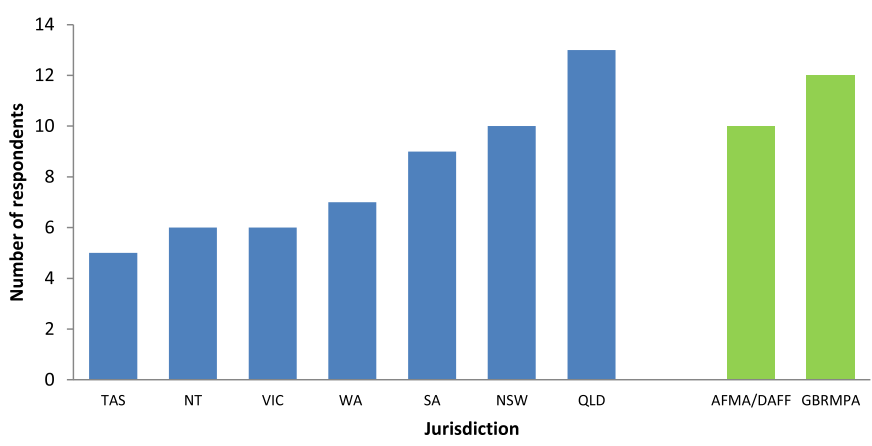

Fig. 2. Survey responses by jurisdiction, with the States represented in blue and the Commonwealth (federal) management agencies in green. (For interpretation of the references to colour in this figure legend, the reader is referred to the web version of this article.) 
Table 2

Social objectives for fisheries management identified through the workshops.

Commercial, recreational and charter communities

1.1 Provide flexible opportunities to ensure fishers can maintain or enhance their livelihood

1.2 Maximise cultural, recreational and lifestyle benefits (including health benefits) of fishing

1.3 Ensure appropriate mechanisms exist for fisher involvement in

development of management advice

1.4 Improve the skills of fishers and fisheries managers participating in management advisory processes

1.5 Stakeholders have a high level of trust in the management of fisheries

1.6 Maximise stewardship of fisheries resources

1.7 Ensure transparency of decision making process by management bodies

1.8 Ensure equitable treatment and access for fishers

1.9 Ensuring access to adequate infrastructure

Indigenous communities

2.1 Maintenance of cultural and heritage values related to fishing activities in indigenous communities

2.2 Ensure provision of access to 'sea country' to enable continuation of traditional activities

2.3 Ensure appropriate consultation of Indigenous people

2.4 Ensure open and transparent communication

2.5 Develop economic opportunities

2.6 Ensure collaborative inputs by Aboriginal communities

Regional and associated communities

3.1 Positively influence fisheries related socioeconomic benefits for regional communities

3.2 Facilitate and support the cohesion and connectedness of fishers with their regional communities through fisheries management

3.3 Maximise community trust in fisheries agencies to manage fisheries

3.4 Ensure fisheries management contributes to the maintenance of cultural and heritage values related to fishing activities

3.5 Facilitate capacity building for community members to enhance stewardship of fisheries resources

community involved those not directly involved in fishing, but affected by fishing through interactions with fishers and their families (e.g. coastal communities) or economically linked to the fishing industry (e.g. suppliers of bait, processors, retailers etc.).

Additional objectives relating to the provision of timely information to each community group were also proposed, but as these objectives related to actions rather than outcomes were not considered in the AHP analysis.

\subsection{Objective priorities}

A hierarchy was developed for the purposes of the AHP analysis with the communities at the highest level, and individual
Table 3

Average relative importance (i.e. weight) of the different objectives expressed as a percentage (total equals $100 \%$ ).

\begin{tabular}{|c|c|c|c|c|c|}
\hline $\begin{array}{l}\text { Objective } \\
\text { number }\end{array}$ & $\begin{array}{l}\text { Short } \\
\text { description }\end{array}$ & $\begin{array}{l}\text { Southern } \\
\text { states }\end{array}$ & $\begin{array}{l}\text { Northern } \\
\text { states }\end{array}$ & $\begin{array}{l}\text { Commonwealth } \\
\text { fisheries }\end{array}$ & $\begin{array}{l}\text { National } \\
\text { average }\end{array}$ \\
\hline \multicolumn{6}{|c|}{ Commercial, Recreational and Charter communities } \\
\hline 1.1 & Flexibility & $10.0 \%$ & $7.2 \%$ & $8.8 \%$ & $9.2 \%$ \\
\hline 1.2 & $\begin{array}{l}\text { Cultural, } \\
\text { lifestyle } \\
\text { benefits }\end{array}$ & $6.9 \%$ & $9.4 \%$ & $5.9 \%$ & $7.1 \%$ \\
\hline 1.3 & $\begin{array}{l}\text { Fisher } \\
\text { involvement }\end{array}$ & $5.3 \%$ & $3.5 \%$ & $5.5 \%$ & $5.0 \%$ \\
\hline 1.4 & Fisher skills & $2.5 \%$ & $2.5 \%$ & $2.8 \%$ & $2.6 \%$ \\
\hline 1.5 & $\begin{array}{l}\text { Trust } \\
\text { management }\end{array}$ & $4.0 \%$ & $4.0 \%$ & $3.4 \%$ & $3.9 \%$ \\
\hline 1.6 & Stewardship & $3.7 \%$ & $3.4 \%$ & $4.9 \%$ & $3.9 \%$ \\
\hline 1.7 & Transparency & $6.0 \%$ & $4.7 \%$ & $4.2 \%$ & $5.3 \%$ \\
\hline 1.8 & Equity & $12.0 \%$ & $6.7 \%$ & $7.4 \%$ & $9.9 \%$ \\
\hline 1.9 & Infrastructure & $8.7 \%$ & $11.7 \%$ & $9.6 \%$ & $9.5 \%$ \\
\hline \multicolumn{6}{|c|}{ Indigenous communities } \\
\hline 2.1 & $\begin{array}{l}\text { Cultural/ } \\
\text { heritage } \\
\text { values }\end{array}$ & $2.5 \%$ & $3.5 \%$ & $3.1 \%$ & $2.8 \%$ \\
\hline 2.2 & $\begin{array}{l}\text { Access to } \\
\text { sea-country }\end{array}$ & $3.0 \%$ & $3.0 \%$ & $3.5 \%$ & $3.1 \%$ \\
\hline 2.3 & Consultation & $2.5 \%$ & $3.6 \%$ & $4.7 \%$ & $3.3 \%$ \\
\hline 2.4 & Transparency & $2.2 \%$ & $3.0 \%$ & $3.2 \%$ & $2.6 \%$ \\
\hline 2.5 & $\begin{array}{l}\text { Economic } \\
\text { opportunities }\end{array}$ & $2.8 \%$ & $4.7 \%$ & $3.1 \%$ & $3.2 \%$ \\
\hline 2.6 & $\begin{array}{l}\text { Collaborative } \\
\text { input }\end{array}$ & $2.8 \%$ & $4.7 \%$ & $3.1 \%$ & $3.2 \%$ \\
\hline \multicolumn{6}{|c|}{ Regional and associated communities } \\
\hline 3.1 & $\begin{array}{l}\text { Fisheries } \\
\text { benefits }\end{array}$ & $13.2 \%$ & $11.4 \%$ & $11.0 \%$ & $12.4 \%$ \\
\hline 3.2 & $\begin{array}{l}\text { Cohesion/ } \\
\text { connectedness }\end{array}$ & $4.9 \%$ & $6.2 \%$ & $6.2 \%$ & $5.5 \%$ \\
\hline 3.3 & $\begin{array}{l}\text { Community } \\
\text { trust }\end{array}$ & $3.6 \%$ & $2.4 \%$ & $3.1 \%$ & $3.2 \%$ \\
\hline 3.4 & $\begin{array}{l}\text { Cultural/ } \\
\text { heritage } \\
\text { values }\end{array}$ & $1.3 \%$ & $1.3 \%$ & $3.0 \%$ & $1.7 \%$ \\
\hline 3.5 & Stewardship & $2.1 \%$ & $3.1 \%$ & $3.7 \%$ & $2.7 \%$ \\
\hline
\end{tabular}

objectives at the lowest level (Fig. 3). The average relative importance of the individual objectives by broad jurisdiction are provided in Table 3, while the distributions around these priorities are illustrated in Figs. 4 and 5. Community level priorities are derived as the sum of the weights of the constituent individual objectives. From these figures, there is considerable variability in the relative importance given to each objective even within jurisdictions.

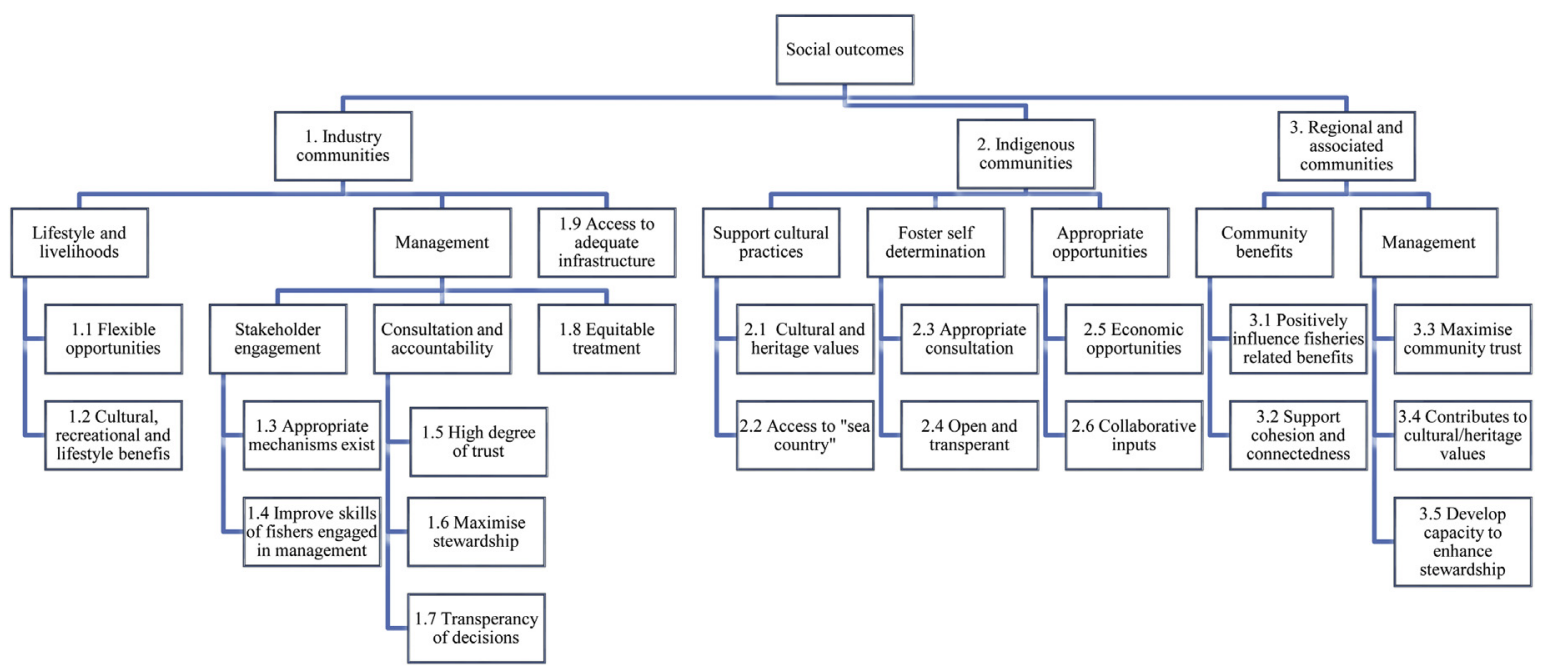

Fig. 3. Social objective hierarchy. 


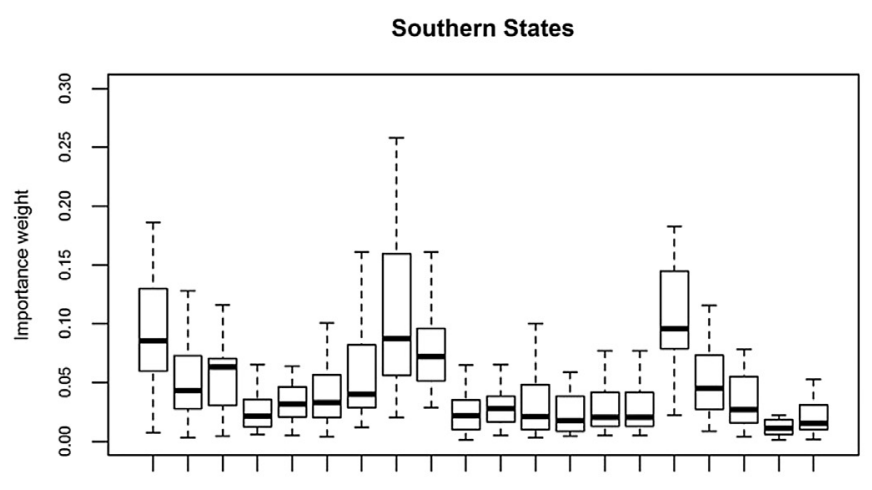

$\begin{array}{llllllllllllllllllll}1.1 & 1.2 & 1.3 & 1.4 & 1.5 & 1.6 & 1.7 & 1.8 & 1.9 & 2.1 & 2.2 & 2.3 & 2.4 & 2.5 & 2.6 & 3.1 & 3.2 & 3.3 & 3.4 & 3.5\end{array}$

Objective

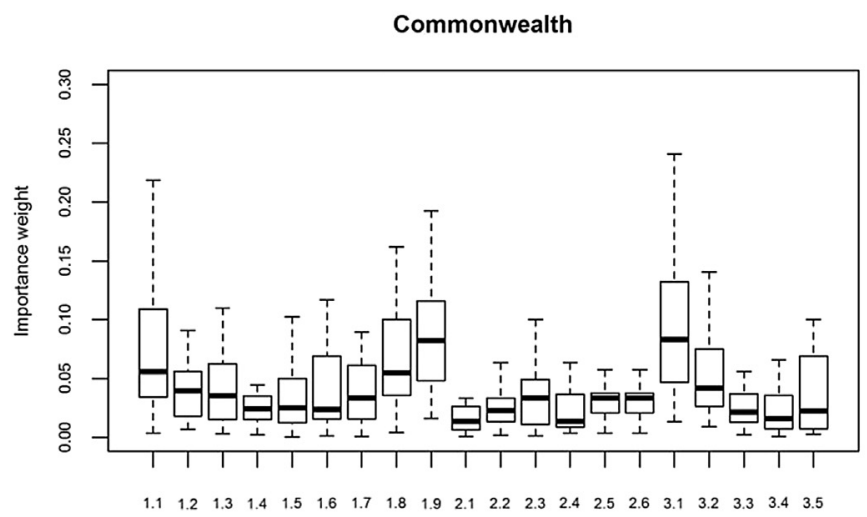

Objective

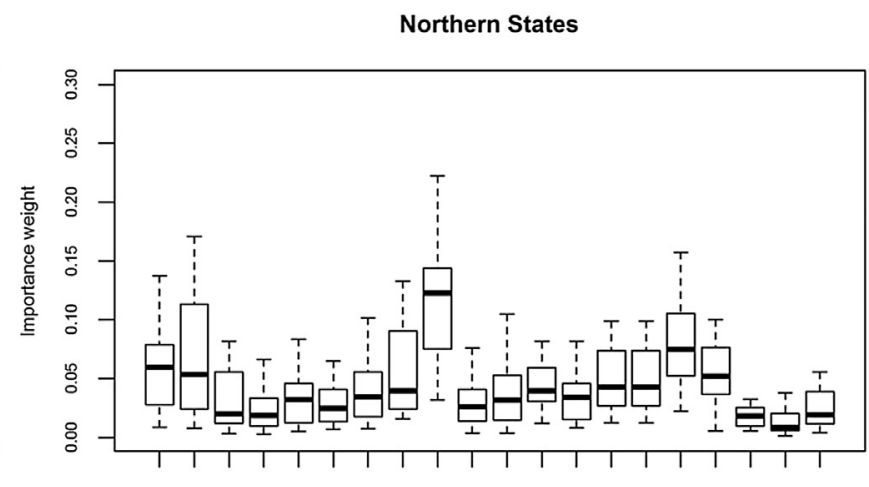

$\begin{array}{llllllllllllllllllll}1.1 & 1.2 & 1.3 & 1.4 & 1.5 & 1.6 & 1.7 & 1.8 & 1.9 & 2.1 & 2.2 & 2.3 & 2.4 & 2.5 & 2.6 & 3.1 & 3.2 & 3.3 & 3.4 & 3.5\end{array}$

Objective

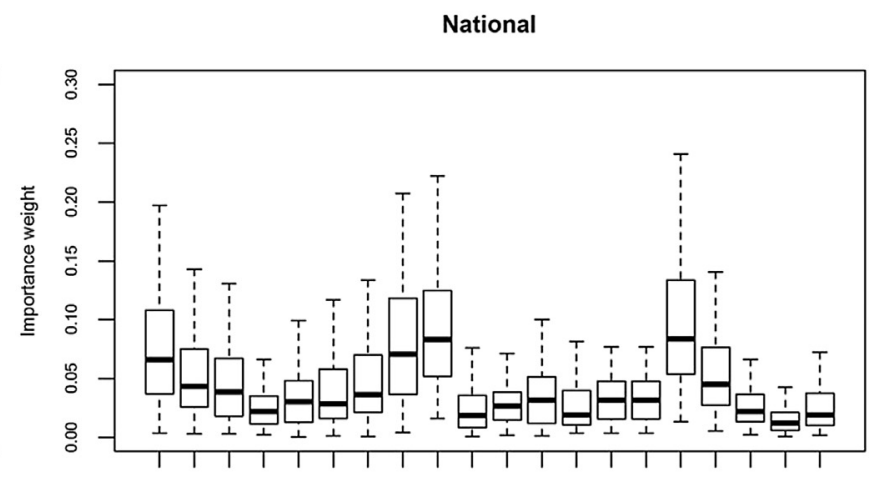

$\begin{array}{llllllllllllllllllll}1.1 & 1.2 & 1.3 & 1.4 & 1.5 & 1.6 & 1.7 & 1.8 & 1.9 & 2.1 & 2.2 & 2.3 & 2.4 & 2.5 & 2.6 & 3.1 & 3.2 & 3.3 & 3.4 & 3.5\end{array}$

Objective

Fig. 4. Distributions of weights at the individual objective level.
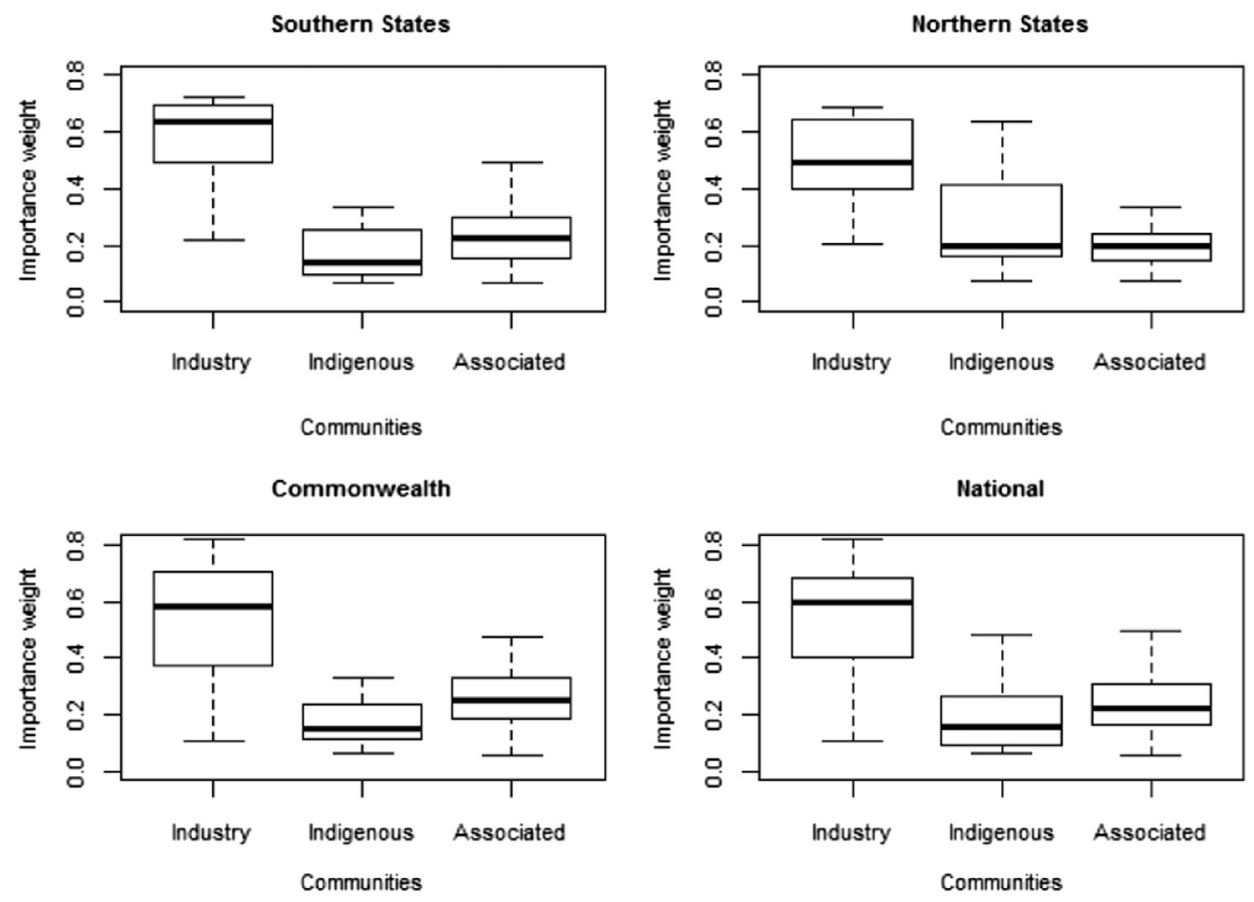

Fig. 5. Distributions of objective weights at the general community level. 
However, certain objectives were consistently considered relatively more important than others. These included objective 3.1: positively influencing fisheries related socio-economic benefits for regional communities; objective 1.9: ensuring access to adequate infrastructure; and objective 1.8: Ensuring equitable treatment and access for fishers. In the southern states, objective 1.1: providing flexible opportunities to ensure fishers can maintain or enhance their livelihood was also considered important. At the broader community level (Fig. 5), objectives relating to the industry were consistently considered more important than objectives relating to the other two communities (i.e. regional and associated communities and indigenous communities).

The level of group coherence is given in Table 4. This indicates the degree to which members of a given stakeholder group have similar or dissimilar objective preferences. At the lower level (i.e. the individual objectives), there was generally low coherence in each jurisdiction (Table 4), with nearly half of the individuals surveyed being considered to have extremely different objective preferences. However, at the community level, coherence was substantially greater, indicating a fairly uniform view as to in which sectors social objectives are most important to achieve.

Given the wide variability in priorities for the different objectives and the general low level of coherence, hierarchical cluster analysis was applied to determine if more homogeneous groups in terms of objective preferences could be determined. Six separate clusters were identified (Fig. 6, see also Figure S2 in the supplementary information). The constituency of each group consisted of individuals across a wide range of jurisdictions. The largest cluster (Cluster 1 ) was fairly equally distributed between the three jurisdiction groups, with the second largest cluster (Cluster 2) dominated by the southern states and the third largest cluster (Cluster 3) dominated by the northern states.

The average weights for each objective within each cluster were derived (Table 5). For simplicity, only the community level objective weights (i.e. aggregated over the individual weights relating to each community), and the top three individual objective weights are presented in Table 5 . The clusters show distinctly differing preferences regarding the social objectives that should be prioritised in fisheries management. Cluster 1 distribute their social objectives preferences somewhat more evenly between commercial sectors and the other two communities, suggesting a belief that fisheries should be managed to achieve outcomes for broader communities and indigenous communities as well as for those who fish. Cluster 3 - dominated by the northern states (Fig. 5) - prioritises social benefits for indigenous communities above the other two communities. Indigenous communities are more predominant in the northern states and hence are likely to have greater interactions with commercial fisheries and fisheries managers, so greater consideration is given to their social needs. Cluster 5 - dominated by southern state individuals - prioritised managing fisheries for social benefit to regional and associated communities above the

Table 4

Coherency scores.

\begin{tabular}{|c|c|c|c|c|}
\hline & \multicolumn{2}{|c|}{$\begin{array}{l}\text { Individual } \\
\text { objective level }\end{array}$} & \multicolumn{2}{|c|}{ Community level } \\
\hline & Score $^{a}$ & Extreme $^{b}$ & Score $^{a}$ & Extreme $^{b}$ \\
\hline Southern States & $88 \%$ & $26 \%$ & $96 \%$ & $0 \%$ \\
\hline Northern States & $86 \%$ & $43 \%$ & $95 \%$ & $0 \%$ \\
\hline Commonwealth fisheries & $80 \%$ & $66 \%$ & $93 \%$ & $0 \%$ \\
\hline National average & $85 \%$ & $46 \%$ & $95 \%$ & $0 \%$ \\
\hline
\end{tabular}

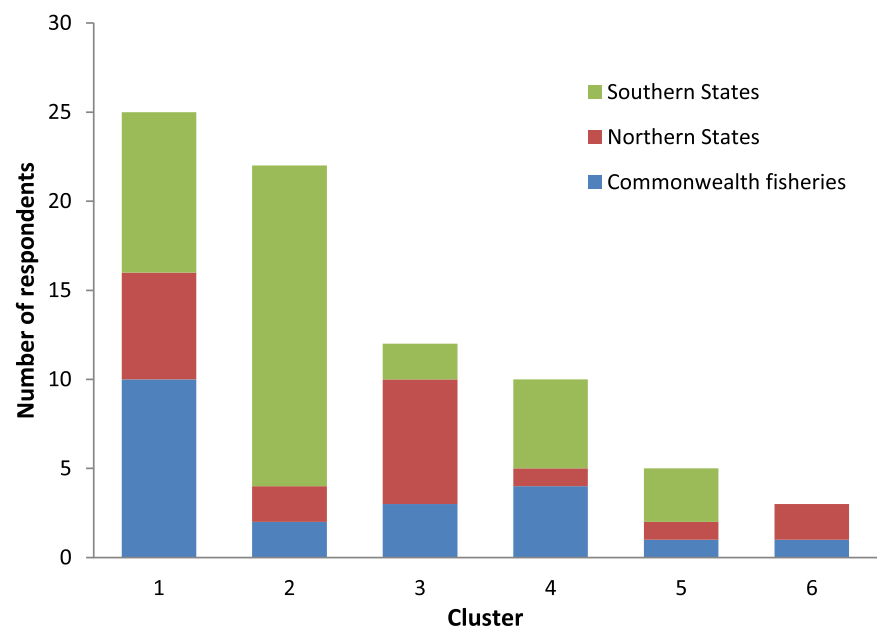

Fig. 6. Composition of more homogeneous clusters.

other two. Clusters 2, 4 and 6 prioritise managing fisheries to benefit fishers (commercial, recreational and charter), but differ in the types of benefits that should be managed for within the commercial, recreational and charter communities. Cluster 2 prioritises flexibility and equal opportunity; cluster 4 prioritises flexibility and access to infrastructure; and cluster 6 - dominated by northern state individuals - on maximising cultural recreational and lifestyle benefits. For cluster 2 - dominated by the southern states - objectives relating to the industry community dominate, both in absolute terms and in terms of including all three top individual objectives.

\section{Discussion}

The lack of explicit social (or other) objectives has several consequences for fisheries policy making and implementation. There is

Table 5

Community level weights and weights of top three objectives by cluster group.

\begin{tabular}{|c|c|c|c|c|c|c|}
\hline & \multicolumn{6}{|c|}{ Cluster } \\
\hline & 1 & 2 & 3 & 4 & 5 & 6 \\
\hline $\begin{array}{l}\text { Commercial, recreational and } \\
\text { charter communities }\end{array}$ & $51 \%$ & $69 \%$ & $40 \%$ & $68 \%$ & $30 \%$ & $69 \%$ \\
\hline $\begin{array}{l}\text { 1.1 Provide flexible opportunities to } \\
\text { ensure fishers can maintain or } \\
\text { enhance their livelihood }\end{array}$ & & $10 \%$ & & $23 \%$ & & \\
\hline $\begin{array}{l}\text { 1.2 Maximise cultural, recreational and } \\
\text { lifestyle benefits (including health } \\
\text { benefits) of fishing }\end{array}$ & & & & & & $37 \%$ \\
\hline $\begin{array}{l}\text { 1.7 Ensure transparency of decision } \\
\text { making process by management bodies }\end{array}$ & & & & & $6 \%$ & \\
\hline $\begin{array}{l}\text { 1.8 Ensure equitable treatment and } \\
\text { access for fishers }\end{array}$ & $7 \%$ & $19 \%$ & & & & \\
\hline $\begin{array}{l}\text { 1.9 Ensuring access to adequate } \\
\text { infrastructure }\end{array}$ & $10 \%$ & $9 \%$ & $10 \%$ & $12 \%$ & & $11 \%$ \\
\hline Indigenous communities & $21 \%$ & $13 \%$ & $44 \%$ & $10 \%$ & $\mathbf{9 \%}$ & $14 \%$ \\
\hline $\begin{array}{l}\text { 2.1 Maintenance of cultural and } \\
\text { heritage values related to fishing } \\
\text { activities in indigenous communities }\end{array}$ & & & $9 \%$ & & & \\
\hline 2.5 Develop economic opportunities & & & $8 \%$ & & & \\
\hline Regional and associated communities & $28 \%$ & $18 \%$ & $16 \%$ & $22 \%$ & $61 \%$ & $17 \%$ \\
\hline $\begin{array}{l}\text { 3.1 Positively influence fisheries related } \\
\text { socioeconomic benefits for regional } \\
\text { communities }\end{array}$ & $11 \%$ & & & $10 \%$ & $43 \%$ & $9 \%$ \\
\hline $\begin{array}{l}\text { 3.2 Facilitate and support the cohesion } \\
\text { and connectedness of fishers with } \\
\text { their regional communities through } \\
\text { fisheries management }\end{array}$ & & & & & $8 \%$ & \\
\hline
\end{tabular}


increasing evidence that fisher compliance is directly linked to perceptions of legitimacy of management policies (Hatcher et al., 2000; Viteri and Chávez, 2007), while fisher community resilience has also been linked to policy perceptions (Marshall, 2007). Awareness of management objectives was found to be a key factor in reducing non-compliance in at least one fishery (Bose and CreesMorris, 2009).

A clear set of objectives are important for reasons other than enhancing compliance. Assessment of fisheries management performance requires benchmarks against which the outcomes of management can be assessed. Many apparent failures of fisheries management may rather be considered success if the implicit objectives also driving policy making were more explicit (Hilborn, 2007). The increasing emphasis on co-management and devolution of greater responsibility to industry also requires explicit objectives to be stated, as bounds within which industry can operate need to be clearly defined (Symes and Hoefnagel, 2010).

The results of this study are a first step in allowing social objectives to be more explicit for Australian fisheries management. Identification of which objectives are the most important allows greater transparency in policy development. As with the majority of studies that have applied social objectives in fisheries multiobjective analysis (Table 1), the key objectives identified from the survey of managers involved ensuring flexibility to enhance fisher livelihood, equity, and enhancing local communities. The exclusion of employment as a social objective was unexpected, as maintaining or increasing employment has previously been the most common social (or at least socioeconomic) objective in many multiobjective analyses of fisheries management systems (see Table 1), and was the only social objective considered in a triple bottom line analysis of all Australian industries (Foran et al., 2005). The main arguments raised by workshop participants in favour of excluding employment as a social objective included that maintaining employment was not seen as their responsibility; and that they could not influence regional employment as they had no direct influence over how many people fishers indirectly employed, where processors are located or how many people these associated businesses employed. Some also considered that employment was more relevant as an economic consideration rather than a social consideration. While employment may not have been considered as a social objective per se, it may still represent an implicit indicator for other, more relevant social objectives, particularly those involving maintaining associated communities or maintaining cultural and traditional activities (Brookfield et al., 2005).

The development of the social objectives was based on identifying the groups that were most likely to be affected by management (i.e. the "communities"), and deriving objectives for each of these communities. However, these objectives may also be reclassified ex post, and an advantage of the AHP process is that weights for these alternative classifications can be derived readily through aggregation of their component objectives. For example, the list of social objectives (Table 2) can be classified into four general groups of maintaining and enhancing (1) social capital (e.g. 1.3; 1.4, 1.5, 1.6; $1.7 ; 2.3 ; 2.4 ; 2.6 ; 3.2 ; 3.3 ; 3.5)$; (2) cultural values (e.g. $1.2 ; 2.1 ; 3.4$ ); (3) access to the resources (e.g. 1.1, 1.8, 2.2); and (3) development (and infrastructure) (e.g. 1.9, 2.5, 3.1); with respective weightings of $0.412,0.116,0.222$ and 0.250 . This provides and alternative means to assess the objectives which may be more comparable with the broader literature on social objectives of fisheries management, while still maintaining an operational or functional list of objectives and priorities for fisheries managers.

The analysis highlights two key challenges for the inclusion of social objectives into fisheries management and policy formulation. Firstly, social objectives are often more multidimensional than economic or environmental objectives. Economic considerations focus on the fishing fleet (and its economic viability), and potentially the local community, although these are often considered social benefits and can therefore also be a social objective. While there is still some debate as to what constitutes maximum economic yield (Christensen, 2010; Grafton et al., 2012, 2010; Pascoe et al., 2013b; Wang and Wang, 2012), achieving it is a well defined - and often singular - economic objective. Similarly, the range of environmental objectives is often limited to the sustainability of key target species, as well as limited to the amount of associated bycatch and other environmental impacts. In contrast, social objectives need to consider welfare of the main users or the resource, whether for commercial, recreational or traditional and cultural reasons, as well as welfare of the broader communities not directly involved in fishing but affected by fisheries management nevertheless. This welfare is affected by not only the level of restrictions imposed (catch or effort), but also how they are imposed, and the opportunities that are afforded to them elsewhere (both within fishing and outside fishing).

The second key challenge is that - even if a set of objectives can be developed and agreed upon as in this study - the relative importance placed on these by managers can vary substantially. The high degree of variability in the objective weights of different managers could reflect the lack of experience in the area. Most managers have previously had to give little consideration to social objectives. Other studies comparing social objectives to economic and environmental objectives have generally found that social objectives overall obtain a relatively low priority (e.g. Pascoe et al., 2013a; Wattage and Mardle, 2005). When presented with a set of specific objectives for the survey, they did not have the advantage of previous discussions by which they could consolidate their views on priorities for social objectives. This may have also influenced the relatively high importance given to the industry community, as managers are more familiar with objectives relating to this group.

However, lack of experience is unlikely to be the main reason for the observed variance in objective weights. In reality, this variance is highlighting that fisheries managers are likely to view differently social objectives depending upon the individual circumstances of different regions and communities. This is evidence in some of the locational differences observed: fisheries managers who worked in regions where there is high indigenous involvement were far more likely to prioritise managing fisheries for the benefit of indigenous communities compared to those where there is limited involvement of indigenous people in fishing activities. More subtle variances could not be identified using our methodology, but are likely to exist.

This again reinforces the complexity of identifying social objectives, which are often highly context specific even when stated at the level of an overall objective. This makes extrapolating these objective preferences to other countries problematic: although the main set of objectives may be more broadly applicable, their relevance and importance in different fisheries is like to vary substantially. Economic and environmental objectives, in contrast, can often be described in generic forms that apply across multiple jurisdictions despite there being substantial differentiation in the actions needed to achieve them in each individual fisheries context. This complexity helps explain why consideration of social objectives is often restricted to relatively broad, nonspecific statements in current fisheries management. It suggests a critical need for individual fisheries to carefully consider what their social objectives are before attempting to put in place social monitoring and evaluation programs. Unless this is done, there is a high risk that managers may focus on social outcomes that are not the highest priorities for their fishery. Managers considering more active consideration and monitoring of social outcomes of their fisheries management should first carefully identify - ideally in close 
consultation with their fishery's stakeholders - the desired social outcomes to be achieved. This process may be time consuming but can result in a clearer articulation of social objectives that can genuinely guide management action, in contrast to current vague specifications which provide little to no direction for managers on the actions they should take to maximise social benefit from their management actions.

\section{Conclusions}

A key outcome of this study is that it has started Australian fisheries managers thinking in terms of explicit social objectives and outcomes - what they can influence and which factors are most important. Mangers in other countries can learn from these experiences, and follow a similar process to derive relevant objectives and weights for their own fisheries. Deriving importance weights provides feedback on what others are thinking, particularly in terms of identifying objectives that are of key importance to key groups of people. Increasing the transparency of current viewpoints will allow similarities to be consolidated into policy, and differences to be explored and debated. If social objectives are to be integrated explicitly into fisheries management in Australia or elsewhere, then such debates are essential.

\section{Acknowledgements}

This study was undertaken as part of the FRDC funded project "Developing and Testing Social Objectives and Indicators for Fisheries Management (FRDC Project 2010/040)". The authors would like to thank the participants at the workshops, and also those who participated in the AHP survey. We would also like to thank James Innes and Trevor Hutton and the three anonymous journal reviewers for comments on an earlier draft of the manuscript.

\section{Appendix A. Supplementary data}

Supplementary data related to this article can be found at http:// dx.doi.org/10.1016/j.ocecoaman.2014.05.014.

\section{References}

Allison, E.H., Ellis, F., 2001. The livelihoods approach and management of smallscale fisheries. Mar. Policy 25, 377-388.

Andalecio, M.N., 2011. Including coastal resource users in fisheries management evaluation of San Miguel Bay, Philippines. Ocean Coast. Manag. 54, 760-770.

Barber, W.E., Taylor, J.N., 1990. The importance of goals, objectives, and values in the fisheries management process and organization: a review. North Am. J. Fish. Manag. 10, 365-373.

Bodin, L., Gass, S.I., 2003. On teaching the analytic hierarchy process. Comput. Operat. Res. 30, 1487-1497.

Bose, S., Crees-Morris, A., 2009. Stakeholder's views on fisheries compliance: an Australian case study. Mar. Policy 33, 248-253.

Brookfield, K., Gray, T., Hatchard, J., 2005. The concept of fisheries-dependent communities: a comparative analysis of four UK case studies: Shetland, Peterhead, North Shields and Lowestoft. Fish. Res. 72, 55-69.

Brooks, K., 2010. Sustainable development: social outcomes of structural adjustments in a South Australian fishery. Mar. Policy 34, 671-678.

Chesson, J., Clayton, H., Whitworth, B., 1999. Evaluation of fisheries-management systems with respect to sustainable development. ICES J. Mar. Sci. 56, 980-984.

Cheung, W.W.L., Sumaila, U.R., 2008. Trade-offs between conservation and socioeconomic objectives in managing a tropical marine ecosystem. Ecol. Econ. 66, 193-210.

Christensen, V., 2010. MEY = MSY. Fish. Fish. 11, 105-110.

Cochrane, K.L., 2000. Reconciling sustainability, economic efficiency and equity in fisheries: the one that got away? Fish. Fish. 1, 3-21.

Coulthard, S., 2012. What does the debate around social wellbeing have to offer sustainable fisheries? Curr. Opin. Environ. Sustain. 4, 358-363.

Cowx, I.G., Van Anrooy, R., 2010. Social, economic and ecological objectives of inland commercial and recreational fisheries. Fish. Manag. Ecol. 17, 89-92.

Davis, A., Wagner, J., 2006. A right to fish for a living? the case for coastal fishing people's determination of access and participation. Ocean Coast. Manag. 49, $476-497$.
Daw, T., Gray, T., 2005. Fisheries science and sustainability in international policy: a study of failure in the European Union's Common Fisheries Policy. Mar. Policy 29, 189-197.

Dichmont, C.M., Pascoe, S., Kompas, T., Punt, A.E., Deng, R., 2010. On implementing maximum economic yield in commercial fisheries. Proc. Natl. Acad. Sci. 107, 16-21.

Duke, J.M., Aull-Hyde, R., 2002. Identifying public preferences for land preservation using the analytic hierarchy process. Ecol. Econ. 42, 131-145.

Foran, B., Lenzen, M., Dey, C., 2005. Balancing Act: a TBL Analysis of the Australian Economy. Department of Environmental and Heritage, Canberra.

Fulton, E.A., Smith, A.D.M., Smith, D.C., 2007. Alternative Management Strategies for Southeast Australian Commonwealth Fisheries: Stage 2: Quantitative Management Strategy Evaluation. Report to the Australian Fisheries Management Authority and the Fisheries Research and Development Corporation. CSIRO Marine and Atmospheric Research, Hobart, p. 400.

Garcia, S.M., Cochrane, K.L., 2005. Ecosystem approach to fisheries: a review of implementation guidelines. ICES J. Mar. Sci. J. Conseil 62, 311-318.

Glaser, M., Diele, K., 2004. Asymmetric outcomes: assessing central aspects of the biological, economic and social sustainability of a mangrove crab fishery, Ucides cordatus (Ocypodidae), in North Brazil. Ecol. Econ. 49, 361-373.

Grafton, Q.R., Kompas, T., Che, T.N., Chu, L., Hilborn, R., 2012. BMEY as a fisheries management target. Fish. Fish. 13, 303-312.

Grafton, R.Q., Kompas, T., Chu, L., Che, N., 2010. Maximum economic yield. Aust. J. Agric. Resour. Econ. 54, 273-280.

Hall, S.J., Mainprize, B., 2004. Towards ecosystem-based fisheries management. Fish. Fish. 5, 1-20.

Hatcher, A., Jaffry, S., Thébaud, O., Bennett, E., 2000. Normative and social influences affecting compliance with fishery regulations. Land Econ. 76, 448-461.

Hilborn, R., 2007. Defining success in fisheries and conflicts in objectives. Mar. Policy 31, 153-158.

Himes, A.H., 2007. Performance indicator importance in MPA management using a multi-criteria approach. Coast. Manag. 35, 601-618.

Innes, J.P., Pascoe, S., 2010. A multi-criteria assessment of fishing gear impacts in demersal fisheries. J. Environ. Manag. 91, 932-939.

Jabareen, Y., 2008. A new conceptual framework for sustainable development. Environ. Dev. Sustain. 10, 179-192.

Lane, D.E., 1989. Operational research and fisheries management. Eur. J. Operat. Res. 42, 229-242.

Leung, P., Muraoka, J., Nakamoto, S.T., Pooley, S., 1998. Evaluating fisheries management options in Hawaii using analytic hierarchy process (AHP). Fish. Res. 36, $171-183$.

Liu, W.H., Ou, C.H., Ting, K.H., 2005. Sustainable coastal fishery development indicator system: a case of Gungliau, Taiwan. Mar. Policy 29, 199-210.

Mapstone, B.D., Little, L.R., Punt, A.E., Davies, C.R., Smith, A.D.M., Pantus, F., McDonald, A.D., Williams, A.J., Jones, A., 2008. Management strategy evaluation for line fishing in the Great Barrier Reef: balancing conservation and multisector fishery objectives. Fish. Res. 94, 315-329.

Mardle, S., Pascoe, S., Boncoeur, J., Le Gallic, B., Garcia-Hoyo, J.J., Herrero, N., Jimenez-Toribio, R., Cortes, C., Padilla, N., Nielsen, J.R., Mathiesen, C., 2002. Objectives of fisheries management: case studies from the UK, France, Spain and Denmark. Mar. Policy 26, 415-428.

Mardle, S., Pascoe, S., Herrero, I., 2004. Management objective importance in fisheries: an evaluation using the analytic hierarchy process (AHP). Environ. Manag. $33,1-11$.

Marshall, N.A., 2007. Can policy perception influence social resilience to policy change? Fish Res, 86, 216-227.

Marshall, N.A., 2010. Understanding social resilience to climate variability in primary enterprises and industries. Glob. Environ. Change 20, 36-43.

Marshall, N.A., Marshall, P.A., 2007. Conceptualizing and operationalizing social resilience within commercial fisheries in northern Australia. Ecol. Soc. 12, 1 [online] URL: http://www.ecologyandsociety.org/vol12/iss11/art11/.

Mascia, M.B., 2003. The human dimension of coral reef marine protected areas: recent social science research and its policy implications. J. Soc. Conserv. Biol. 17, 630-632.

Nielsen, J.R., Mathiesen, C., 2006. Stakeholder preferences for Danish fisheries management of sand eel and Norway pout. Fish. Res. 77, 92-101.

Nunan, F., 2013. Wealth and welfare? Can fisheries management succeed in achieving multiple objectives? A case study of Lake Victoria, East Africa. Fish. Fish. 15, 134-150.

OECD, 2012. OECD Review of Fisheries 2011. OECD Publishing, Paris.

Pascoe, S., Bustamante, R., Wilcox, C., Gibbs, M., 2009a. Spatial fisheries management: a framework for multi-objective qualitative assessment. Ocean Coast. Manag. 52, 130-138.

Pascoe, S., Dichmont, C.M., Brooks, K., Pears, R., Jebreen, E., 2013a. Management objectives of Queensland fisheries: putting the horse before the cart. Mar. Policy 37, $115-122$.

Pascoe, S., Dichmont, C.M., Vieira, S., Kompas, T Buckworth, R.C., Carter, D., 2013b. A retrospective evaluation of sustainable yields for Australia's northern Prawn fishery: an alternative view. Fisheries 38, 502-508.

Pascoe, S., Proctor, W., Wilcox, C., Innes, J., Rochester, W., Dowling, N., 2009b. Stakeholder objective preferences in Australian Commonwealth managed fisheries. Mar. Policy 33, 750-758.

Phillipson, J., Symes, D., 2013. Science for sustainable fisheries management: an interdisciplinary approach. Fish. Res. 139, 61-64.

Plagányi, É.E., van Putten, I., Hutton, T., Deng, R.A., Dennis, D., Pascoe, S., Skewes, T., Campbell, R.A., 2013. Integrating indigenous livelihood and 
lifestyle objectives in managing a natural resource. Proc. Natl. Acad. Sci. 110, 3639-3644.

Saaty, T.L., 1980. The Analytic Hierarchy Process. McGraw-Hill, New York.

Schirmer, J., Casey, A.M., 2005. Social Assessment Handbook: a Guide to Methods and Approaches for Assessing the Social Sustainability of Fisheries in Australia. Fisheries Research and Development Corporation ESD Reporting and Assessment Subprogram Publication No. 7. Bureau of Rural Sciences, Canberra.

Soma, K., 2003. How to involve stakeholders in fisheries management - a country case study in Trinidad and Tobago. Mar. Policy 27, 47-58.

Stouten, H., Heene, A., Gellynck, X., Polet, H., 2011. Policy instruments to meet fisheries management objectives in Belgian fisheries. Fish. Res. 111, 8-23.

Symes, D., Hoefnagel, E., 2010. Fisheries policy, research and the social sciences in Europe: challenges for the 21st century. Mar. Policy 34, 268-275.

Symes, D., Phillipson, J., 2009. Whatever became of social objectives in fisheries policy? Fish. Res. 95, 1-5.

Tobin, R.C., Sutton, S.G., Penny, A., Williams, L., Maroske, J., Nilsson, J., 2009. Baseline Socio-Economic Data for Queensland East-Coast Inshore and Rocky Reef Fishery
Stakeholders. Part A: Commercial Inshore and Rocky Reef Fishers. Fishing and Fisheries Research Centre Technical Report No. 5. James Cook University, Townsville.

Urquhart, J., Acott, T., Reed, M., Courtney, P., 2011. Setting an agenda for social science research in fisheries policy in Northern Europe. Fish. Res. 108, 240-247.

Viteri, C., Chávez, C., 2007. Legitimacy, local participation, and compliance in the Galápagos Marine Reserve. Ocean Coast. Manag. 50, 253-274.

Wang, Y.-G., Wang, N., 2012. A retrospective evaluation of sustainable yields for Australia's Northern Prawn Fishery. Fisheries 37, 410-416.

Ward, J.M., Kelly, M., 2009. Measuring management success: experience with United States fisheries. Mar. Policy 33, 164-171.

Wattage, P., Mardle, S., 2005. Stakeholder preferences towards conservation versus development for a wetland in Sri Lanka. J. Environ. Manag. 77, 122-132.

Zahir, S., 1999a. Clusters in a group: decision making in the vector space formulation of the analytic hierarchy process. Eur. J. Operat. Res. 112, 620-634.

Zahir, S., 1999b. Geometry of decision making and the vector space formulation of the analytic hierarchy process. Eur. J. Operat. Res. 112, 373-396. 